Relations industrielles

Industrial Relations

\title{
Blackmur, Douglas, Strikes: Causes, Conduct and Consequences
}

\section{Braham Dabscheck}

Volume 50, numéro 2, 1995

URI : https://id.erudit.org/iderudit/051025ar

DOI : https://doi.org/10.7202/051025ar

Aller au sommaire du numéro

Éditeur(s)

Département des relations industrielles de l'Université Laval

ISSN

0034-379X (imprimé)

1703-8138 (numérique)

Découvrir la revue

Citer ce compte rendu

Dabscheck, B. (1995). Compte rendu de [Blackmur, Douglas, Strikes: Causes, Conduct and Consequences]. Relations industrielles / Industrial Relations, 50(2), 456-458. https://doi.org/10.7202/051025ar

Tous droits réservés @ C Département des relations industrielles de l'Universite Laval, 1995
Ce document est protégé par la loi sur le droit d'auteur. L’utilisation des services d'Érudit (y compris la reproduction) est assujettie à sa politique d'utilisation que vous pouvez consulter en ligne.

https://apropos.erudit.org/fr/usagers/politique-dutilisation/ 
autrement. Toutefois, quand le mouvement syndical est divisé entre modérés et activistes (radicals au sens nordaméricain), cette stratégie est contreproductive car les employeurs réservent leurs concessions aux modérés qui font moins grève. Il est aussi notable que l'auteur considère que c'est le nombre de grèves qui est plus important que leur succès ou leur échec. Ce n'est pas de gagner une grève qui augmente les salaires. Les défaites peuvent être plus productives que les victoires, car les résultats acquis sont eux-mêmes relatifs au caractère important des revendications, qui génèrent une réputation d'activisme pour un syndicat.

Indiscutablement, l'idée est intéressante, et l'auteur expose clairement sa démarche. Cependant, l'ouvrage soulève plusieurs questions. D'une part, il se place dans une perspective théorique bien définie, ce qui amène à des simplifications que tous ne partageront pas. Il est, par exemple, un peu rapide d'affirmer en le tenant pour acquis au-delà de toute controverse que "le compromis de classe corporatiste abaisse les salaires " si il augmente le taux et la sécurité de l'emploi. Nombre de ceux qui ont étudié l'Allemagne et la Scandinavie peuvent avoir une opinion différente. Il est aussi simplificateur, et même un peu naïf, d'écrire que, alors que les salariés ne peuvent faire l'expérience de la grève et de son effet sur les salaires que tous les quatre ans (surtout en France !), les managers obtiennent des données quasi quotidiennes de l'effet sur les prix des volumes de ventes et des profits et qu'ils peuvent librement expérimenter en montant ou en descendant les prix pour en observer les effets. D'autres exemples pourraient être fournis tel l'utilisation du "pouvoir de classe" des mineurs, qui veut sans doute dire leur pouvoir de négociation, surtout quand il est basé, comme il l'est noté, sur l'appui de l'État, capitaliste en l'occurrence.

D'autre part, l'auteur, pour appliquer les techniques statistiques qu'il utilise, est naturellement amené à coder certaines de ses données. Les choix opérés alors, tels la décision de considérer un département comme "syndiqué " ou non, la correction des statistiques par les comptes-rendus de grèves, amènent, comme dans tous les cas d'études similaires, le lecteur à se demander si un résultat légèrement différent n'aurait pas été obtenu avec un codage lui aussi différent. Cependant, le fait que l'analyse statistique soit ensuite confortée par une analyse historique des sites concernés pallie dans une certaine mesure cet inconvénient. Le chapitre le moins convainquant est sans doute le dernier qui tente de généraliser les résultats de l'étude.

En résumé, l'ouvrage est intéressant et la thèse qu'il avance est provocante. Cependant, cette interprétation de l'exemple des mineurs de charbon français sous la troisième république suffit-elle à condamner les apports de l'école du Wisconsin aux relations professionnelles et à affirmer la supériorité générale du modèle de syndicalisme militant de conflit de classes en matière de salaires comme le fait son auteur? Le présent recenseur en doute fortement.

JACQUES ROJOT Université de Paris 1

\section{Strikes: Causes, Conduct and Consequences}

by Douglas BLACKMUR, Sydney, Federation Press, 1993, 232 p., ISBN 1-86287$114-0$

How powerful a tool is the mind? To what extent can the mind be harnessed to derive an understanding of real world phenomena? To understand the real world do we need to somehow or other become acquainted with literally every detail of that which becomes the object of our curiosity? Or is it possible to use 
our mind to develop and test theories to fill in gaps which are beyond our sensory perception? Did Einstein have to travel in outerspace throughout eternity to develop his theory of relativity?

For example, let us consider the issue of major industrial disputes whether they be strikes or lockouts disputes which last for a goodly period of time. During the passage of such disputes the protagonists will use any tactic, subject to 'moral' and 'legal' codes, in seeking to prevail. As in war, 'truth' will be the first casualty of the dispute. A government - even, if not especially, one with supposedly strong union and worker connections - will exercise the power available to it to crush an adversary which seeks to move outside a traditional framework (such as arbitration provided by industrial tribunals) and use alternative means (direct action) in pursuit of its goals. Moreover, compared to private sector employers, government have a wider array of means available to them, ranging from press censorship, jailings and state-induced violence, to crush opponents. Strikes and lockouts, after all, are not games of tiddly-winks; they involve dramatic illustrations of authority struggle where rivals are seeking to either assert or usurp domination and control. As industrial disputes continue one would expect sections within various protagonists to oscillate between adopting a tough and firm line ("we will really teach them a lesson this time!") to finding a solution to end the tension and emotions associated with the dispute. Think of your own wonderful record in disputes with 'loved' ones.

These issues are of relevance in light of Douglas Blackmur's Strikes: Causes, Conduct and Consequences, which is derived from a Ph.D. thesis he completed in 1986. In Strikes Blackmur provides a detailed and exhaustive account of two strikes which occurred in Queensland shortly after World War II. The first involved meatworkers in 1946 and centred on the issue of a seniority system.
The second was a 1948 dispute between railway workers and the Hanlon Labor government (as employer) over the issue of wage increases.

Blackmur employs, or in his words 'celebrates... the use of traditional historical methods' (p. 212) in examining these disputes. He has been most assiduous in examining archival and other material in documenting the various twists and turns of both these major Queensland disputes. Or, to put it another way, Blackmur eschews the use of what he calls social science theories in attempting to 'understand' these episodes of high drama. At best, Blackmur's work can be regarded as an exercise in induction (his empirical data produces 'propositions', or 'statements' alluded to in the second paragraph of this review), at worst what Dunlop would refer to as a mountain of facts. It is clear that Blackmur is unhappy or unprepared to indulge in social science theorizing because such theories have a predilection to 'significant unforeseen consequences' (p. 211). He is only prepared to make 'statements' which are solidly based on a document that he has uncovered in his research.

Two examples may help to illustrate this. First, Blackmur provides three initial chapters which seek to situate post war Queensland industrial relations in an 'appropriate' context. These chapters are well done. However, in the introduction he states: 'I do not, however, pretend for one moment that this book provides a definitive evidence of casual links (or a lack of such links) between all of the contextual variables in their chapters and the dynamics of the Meat and Railway Strikes. Ideally, this is what establishing the nature of the relationship between context and particular historical event requires' (p. xiv). The problem for Blackmur, with his use of traditional historical methods, is that he cannot actually 'see' a connection between context and events; documents rarely, if ever, formally state that the 
reason why action (internally) has been initiated is because of a change in some external variable. It is the role of scholars to theorize and 'develop' such linkages, to provide an understanding or explanation of real world phenomena.

Second, as Blackmur's title suggests, one of the contributions of his book is to consider the 'consequences' of the two disputes. However he finds himself trapped by his methodology. Because he hasn't actually examined the historical record (and in considering 'consequences' where does one stop?), other than immediately after the cessation of the disputes, he can only provide a 'preliminary' explanation, offer suggestions (is this akin to theorizing?), raise questions and state that the book has been only able to scratch the surface of a potentially highly fruitful field of research' (p. 206). Does this mean that after ten or fifteen years of enquiry, he feels compelled to pass the baton on to someone else?
Industrial relations scholarship has often been criticized for its lack of a theoretical orientation - or what Blackmur might refer to as 'impotent empiricism' (p. 212). It will be asserted here that a necessary prerequisite of a discipline, and of scholars who inhabit its space, is to indulge and experiment in theoretical discourse, to develop and test theories. In a sense all social phenomena is of the order of 'significant unforeseen consequences'. One isn't an historian to celebrate a methodology. The essential epistomological function of historical scholarship is that it provides empirical data upon which theories can be tested and developed, thereby providing us with an understanding of the real world of 'significant unforeseen consequences'. To return to the question of how powerful a tool is the mind - if you don't try to use it, you will never find out!

BRAHAM DABSCHECK

The University of New South Wales

\section{Travail et emploi: le temps des métamorphoses}

sous la direction de Michel LALLEMAND, Paris, L'Harmattan, Collection "Logiques sociales ", 1994, 283 p., ISBN 2-7384-2559-3.

Ce volume rassemble les contributions de 11 auteurs qui analysent les transformations en cours dans l'emploi et le travail. C'est un ouvrage ambitieux car le défi que les auteurs se sont imposés est considérable. Il s'agit de dresser un bilan des changements de l'emploi et du travail tant au plan de la dynamique des organisations que des mutations dans le marché du travail, puis de présenter les nouvelles voies théoriques qui s'ouvrent afin d'analyser les configurations sociales et économiques récentes dans deux disciplines, l'économie et la sociologie. Avec un tel projet, peut être un peu trop ample pour un seul volume, le lecteur comprendra que chaque chapitre couvre de façon succincte les différents aspects abordés selon l'expertise de l'auteur. Les sujets traités sont universels mais la France sert d'exemple pour la dimension empirique. Le lecteur trouvera dans ce volume une analyse des principales conséquences de la mise en place d'un nouvel ordre économique pour l'emploi et le travail.

La première partie est divisée en six chapitres dans lesquels différents auteurs traitent du chômage comme d'un phénomène permanent (chap. I), des nouvelles formes d'organisation du travail et de l'entreprise (chap. II), de la technologie dans ses rapports à l'emploi et 